\title{
Female offenders of human trafficking and sexual exploitation
}

\section{Miriam Wijkman ${ }^{1}$ (D) Edward Kleemans ${ }^{1}$}

Published online: 10 May 2019

(C) The Author(s) 2019

\begin{abstract}
Female offenders are seldom studied by criminological scholars. This is certainly the case regarding offenses like human trafficking and sexual exploitation. However, the number of women suspected of being a perpetrator of human trafficking should not be underestimated. In this paper we present the results of a study on female perpetrators of human trafficking. We have analyzed the court-files of 150 women who have been convicted for human trafficking. We present results on the prevalence of female offenders of human trafficking and the forms of exploitation they have been convicted for. After this we present the sanctions that were imposed on the women and the offender, offense and victim characteristics. This paper concludes by discussing implications for criminal justice authorities, policy and research.
\end{abstract}

Keywords Human trafficking · Female offenders · Commercial sexual exploitation · Victimization

\section{Introduction}

Criminologists seldom study female offenders and this applies even more to women who have committed serious offenses, such as human trafficking and sexual exploitation. Over the period 2011-2015, the Dutch Public Prosecution Service registered a total of 1332 suspects of trafficking in human beings. On average, $17 \%(N=227)$ of the suspects were women. In the Netherlands, this man-woman distribution of roughly 5:1 is more or less the same [15]. Worldwide, 38\% of the suspected perpetrators of human trafficking are female $[25,26]$. Women from Central Europe and East Asia are even twice as likely to be a suspect of human trafficking than men (68\% versus 32\%) [25, 26]. Research by Van Dijk et al. [28] into prostitution-related human trafficking in the

Miriam Wijkman

m.wijkman@vu.nl

1 Faculty of Law, Department of Criminal Law and Criminology, Vrije Universiteit Amsterdam, De Boelelaan 1105, 1081 HVAmsterdam, The Netherlands 
Netherlands between 1997 and 2000, shows that a quarter of the perpetrators were female. A small part (14\%) of this group of women were considered by the police as one of the leaders of the criminal organization [28]. Staring [22] reports that, in most cases, women are part of the criminal group. These figures demonstrate that the proportion of female perpetrators in human trafficking should not be underestimated. Despite these considerable numbers of female suspects, little research has been conducted into this phenomenon. Therefore, theoretical and empirical advancement in this area is nearly absent.

In the Netherlands, no systematic and representative research has been conducted into women and their involvement in trafficking in human beings that describes the background and role of these women. This study explores the prevalence and characteristics of women who are convicted of human trafficking. Specific question examined include:

1. How many women were suspected and convicted of trafficking in human beings during the period 1994-2016?

2. For what forms of exploitation within human trafficking have these women been convicted?

3. What sanctions have been imposed on these women?

4. What are the offender and offense characteristics of women who have been convicted of human trafficking?

The next section reviews previous research on human trafficking and sexual exploitation, particularly the involvement of female offenders and their roles in the commission of these criminal activities. The methods section describes the selection of case files (involving a female perpetrator) that have been analyzed. The results section presents findings on the prevalence of women convicted for human trafficking, prosecution characteristics, offender characteristics, offense characteristics, behavioral acts committed by the women, and victim characteristics. Particular attention is paid to deception and economic vulnerability as well as to sexually exploited female perpetrators. The last section provides a conclusion and discussion of the main findings.

\section{Previous research on human trafficking and sexual exploitation}

Conducting research on human trafficking and sexual exploitation is a precarious endeavor, as different definitional problems and ideological views often dominate the discussion. Regarding the definitional problems, a great deal of debate surrounds whether a person's consent is relevant; the differences between smuggling and trafficking; whether transit from one place to another is a needed element in human trafficking; whether trafficking is distinct from slavery, or is synonymous; and the exact definition of exploitation (see for a indepth analysis of these problems [33]). Furthermore, ideological views also play a role in the debate. A prominent one, as expressed by radical feminist authors (e.g. [2, 9, 17]), entails that prostitution is by definition a form of violence by men against women. This approach means that there is no distinction between forced and voluntary prostitution and that some type of violence, always executed by men against women, is always present. Prostitution, in this 
view, is something done to women, not something that can be chosen. However, prostitutes themselves may view their work in more neutral terms, such as 'sex work', or they consider themselves to be 'working woman'. These authors, however, reject the idea that prostitution is sex work because viewing it as work might legitimize prostitution [32]. In their view, prostitution is a form of sexual violence and is considered as a human rights violation [18]. Therefore, working as a prostitute cannot be seen as having a normal, legitimate job. On the other hand, some authors favoring legalization of prostitution also present quite radical or utopian ideological views in which many negative aspects of the prostitution industry would vanish like snow in summer as soon as prostitution would become legalized (for a review, see e.g. [8]).

Ideological views are strongly present in the discussion on prostitution and, therefore, also in research on sexual exploitation and human trafficking. According to Weitzer [32], authors and advocacy groups regarding the sex industry as a despicable industry $[2,9,17]$ would exaggerate claims to get funding and their views incorporated in government policy. Many studies of prostitution would lack an independent view [21] and have a poor methodological foundation [13]. Anecdotes are routinely presented as conclusive evidence, and counterevidence is often ignored. [32]. These ideological views also influence how the relationship between prostitution and human trafficking is viewed [16]. According to the radical feminist views, prostitution and human trafficking are inextricably linked because prostitution drives trafficking. According to this view, the best way to stop trafficking is to eradicate prostitution. Consequently, the methodological problems that are present in studies on prostitution can also be found in studies on human trafficking. Systematic and thorough empirical research is limited. Only a third of all studies contain original data with research findings [36]. A literature review of 1500 diverse publications found that less than a third of the studies contained empirical studies and that studies are often based on convenience samples, samples that cannot be identified, or, it is unclear on which data and methods the studies are based. The studies that were based on some form of data collection, relied heavily on anecdotal stories and interviews with 'key stakeholders' [6].

Estimating the scope of human trafficking has largely remained guesswork. Claims of global organizations, such as the United Nations, and government agencies, such as the US government, were used as empirical evidence, although these organizations often fail to disclose their data sources and methodologies [36]. Agencies publishing human trafficking estimates also seemed to support one another by quoting each other's numbers. Agencies under the United Nations would use numbers quoted in reports of the US government and vice versa [36]. However, to provide as good a picture as possible on human trafficking and sexual exploitation, it was decided to present the findings of the most recent report of the [27]. Despite methodological flaws (e.g. the use of different definitions for human trafficking, the use of different datasources by each country, not every country is included in every analysis), the UNODC provides the most recent information on human trqfficking and exploitation worldwide.

Estimations are that, in $2014,38 \%$ of the victims were trafficked for forced labor, $54 \%$ for sexual exploitation, and $8 \%$ for other forms. It is unclear on how many countries this finding is based. Half (51\%) of all victims were women, $21 \%$ were men, $20 \%$ girls of 17 years and below, and $8 \%$ boys (based on data of 85 countries). 
The victims of sexual exploitation were in $96 \%$ of the cases women/girls,compared to $4 \% \mathrm{men} /$ boys. For labor exploitation, the numbers were reverse: $37 \%$ of the victims were women/girls, and $63 \%$ were men/boys; for trafficking for organ removal, $18 \%$ of the victims were women/girls and $82 \%$ were men/boys (results based on 71 countries). Data from the 2012-2014 period shows that a majority of victims (57\%) are trafficked transnationally (across at least one international border). The remaining victims are trafficked domestically/within national borders. Traffickers and their victims often have the same ethnic background. It is unclear on how many countries this finding is based. In 2014, the majority (63\%) of the convicted traffickers were men and $37 \%$ were women (based on data of 66 countries). Another report from UNODC suggested that women in organized criminal networks participated more in lower-ranking activities, such as the recruitment of victims, while men tended to engage in higher ranking activities, such as organizational or exploitation roles $[25,26]$.

\section{Involvement of female perpetrators of human trafficking}

There are various offending pathways that can explain how women become involved as a perpetrator in human trafficking. Traditionally, women are viewed as victims of sexual exploitation [23]. If they become involved as perpetrators, it is often assumed that they are or were victims of sexual exploitation themselves. On a fairly regular basis, it happens that women who have been sexually exploited first, later join the criminal partnership and start to exploit other women themselves $[12,24]$. Often a romantic relationship exists between the prostitute and one of the perpetrators $[4,22$, 30]. For these women, the transition from prostitute to perpetrator is perhaps a way to stop working as a prostitute $[4,24]$.

Human trafficking and sexual exploitation are often viewed as offenses committed only by men who benefit from the vulnerable position of women. Within this 'creepy male-vulnerable woman' image, a clear distinction is made between perpetrators and victims: a victim can never be a perpetrator, and a woman, therefore, can never be involved as a perpetrator in sexual exploitation [7]. It is unclear, however, for how many female perpetrators of human trafficking this statement really applies. As mentioned earlier, there are several limitations to previous studies. It is important to bear in mind that there are also women who have not been sexually exploited in an earlier stage of their lives and for other reasons become involved in exploitation. These other reasons have hardly been studied, but some research exists for the wider topic of female involvement in organized crime. In the case of female perpetrators of drugs trafficking, financial motives play a role [1] and female perpetrators of human smuggling indicate that they wanted to help friends or have a financial motive [37]. In general, women can be involved in various criminal activities, such as drugs smuggling, human smuggling, and trafficking for sexual exploitation, and that they do not only fulfill supporting but also more prominent roles ([10]: 27-29; [11]).

\section{Roles of women involved in human trafficking and sexual exploitation}

In general, female perpetrators of sexual exploitation are primarily viewed as the ignorant wife or girlfriend of a male perpetrator [20]. Women often have a supporting role and have been instructed by their male partner to use their femininity and female 
characteristics when committing the offense [19]. For example, women can be used by men to select and recruit other women to get them to work as a prostitute. The assumption here is that a female recruiter can more easily gain trust than a male recruiter, simply because she is a woman. These women would not only work as a recruiter, but also as a kind of guardian for the victims when they are put to work in the country of destination $[25,26]$.

Women are often involved in the recruitment process; the literature also shows that they have management positions in which they are responsible for bookkeeping and earnings [25], transport to the country of destination, monitoring of prostitutes in the brothels where they are working, and the forgery of passports [3]. Broad [4] concluded in her research that female perpetrators of sexual exploitation were convicted for criminal activities at a lower level and that they are also more exposed to detection by investigative authorities. Siegel and de Blank [20] indicated that, in the Netherlands, the role of female perpetrators in human trafficking organizations from Italy, Eastern Europe, and Nigeria seems to be increasing.

\section{Scientific and societal relevance}

Trafficking in human beings has been a priority for the Dutch police for many years, but investigation and prosecution encounter various problems, as is also the case in many other countries. As mentioned earlier, the (international) scientific literature pays little attention to female perpetrators of trafficking in human beings, while it is estimated that their share in the offense is relatively large. In the process of prosecuting human traffickers, female perpetrators are usually seen as an assistant or victim. However, there are indications that they have a more prominent role than is assumed. If these women are - wrongly - not regarded as perpetrators or are prosecuted less often than men, it is possible that networks will continue their work and continue to recruit and use victims for sexual exploitation. Because of the major damage caused by this type of offense and its impact on victims, it is important to gain more knowledge about this group. This research identifies the role female offenders have in sexual exploitation and to what extent their own victim experiences of sexual exploitation play a role. This research does not only extend the theoretical and empirical understanding of the phenomenon of human trafficking, and provides important information for the investigation and prosecution of suspects of human trafficking for sexual exploitation.

\section{Methods}

For this study, the Dutch Prosecution Office provided the records of adult women (18 years and older) who have been a suspect and have been convicted for human trafficking in the period 1991-2016. During this period, the legal history regarding human trafficking was subject to considerable developments: from article 250ter of the Penal Code, to article 250a, to article 273a and, finally, to article $273 \mathrm{f}$. All these different legal articles were included in the study. The judicial documentation of these perpetrators were analyzed and they entail a total research group of over 400 offenders. Since this group was too large for the current study and 
corresponding timeframe, it was decided to investigate the convicted women within 2 large districts and 2 smaller districts: Amsterdam $(N=65)$, Rotterdam $(N=44)$, 's-Hertogenbosch $(N=19)$, and Alkmaar $(N=10)$. This resulted in a total of 138 women who had been convicted of human trafficking.

Permission was received from the Board of Procurators General (in charge of the Prosecution Office) to analyze the court files of these women. All the cases went to trial because the Netherlands does not have a system of plea-bargaining. The analysis of the court files was done with the aid of the scoring instrument 'Female Sex Offenders' that was used in the research by Wijkman et al. [35]. This instrument is the basis of various investigations regarding women who have committed serious (sex) offenses. Important variables have been added to this instrument relating to the offense of trafficking in human beings, such as characteristics of the partnership, the content of the relationship between the female perpetrator (s) and the co-perpetrators, and characteristics of the criminal activities that led to the conviction. More details about the scoring instrument can be found in Appendix 1.

The information in the court files was scored by the first author and a second senior researcher, assisted by three Master students (two in Criminology and one in Clinical Psychology). Each had been trained in analyzing and scoring court files. All scorers were instructed to code only information as explicitly written in the reports or files, and not to interpret any contextual information. At the beginning, ten randomly selected files were coded by two scorers, and coding was compared. It appeared that the information in the court files was, in general, clear and factual. Almost all court files were unambiguous and there was little doubt about the interpretation of the information. Agreement was generally perfect, with only some discrepancies in scoring values either as 'not present' or 'missing' - which does not affect the later analysis.

In the court files, as compiled by the Public Prosecution Service in preparation for the criminal case, characteristics of the perpetrator, the offense, and the victim can be found. It contains information about the indictment and usually also the judgment. The indictment contains the facts of which the suspect is suspected, when the suspect committed the offense(s), and with regard to which victim(s). The birth dates of the victims are also included in the indictment. Furthermore, testimonies and reports of victims are included in the files. Depending on the nature of the case, information reports from the Probation Service or psychiatric/ psychological reports may also be available.

Several files, $62(45 \%)$, were unavailable for analysis: $31(22.5 \%)$ were untraceable, 26 (18.8\%) were not (yet) available because the file was still at the Public Prosecutor's Office because of appeal, $3(2.2 \%)$ files had already been cleared, and $2(1.4 \%)$ files - cases had been transferred to foreign countries for prosecution. Further analyses showed that these unavailable cases mainly concerned recent cases that took place after 2010 .

For the 62 files that were unavailable for analysis, it was checked whether these cases were included in the database of rechtspraak.nl. ${ }^{1}$ By doing this, it was possible to trace 18 extra cases and the required information about the offense could at least be

\footnotetext{
${ }^{1}$ Rechtspraak.nl is a database containing judicial decisions that may be important for the Dutch legal system or society.
} 
analyzed from the court verdict. In total, there is information about 94 cases (68\% of the total number of 138 cases) involving a female perpetrator.

For some empirical results, brief case descriptions have been added. These descriptions have been deliberately changed regarding distinctive features in order to guarantee the privacy of the persons examined and thus prevent recognition. This change also applies to the names of the persons involved.

\section{Results}

\section{Prevalence of women convicted for human trafficking}

When a perpetrator enters the Dutch criminal justice system, she and her crime are recorded at several levels. First, a perpetrator and her case are registered by the police, after which the case may be sent to the prosecution service where it is then registered. A perpetrator is then called a suspect and she is charged with the crime. When the prosecutor decides to bring the case in front of a judge, the case goes to court where a judge decides on the case, conviction or acquittal. All the cases went to trial because the Netherlands does not have a system of plea-bargaining, which implies that all cases have been convicted for the main charge(s).

In the current research group, 712 women in total were suspected of trafficking in human beings (including 19 juvenile offenders) in the period 1991-2016, and 422 women (including 15 juvenile offenders) were convicted. Over a period of 23 years, this amounts to an average of 30 suspects and 18 convicts per year.

The number of cases notified to the Public Prosecution Service varies greatly, which can also be seen in Fig. 1. Therefore, it is difficult to make inferences about the effect of, for example, a stricter investigation policy. ${ }^{2}$

The average age of the offenders at the time of the offense was 32.3 years (minimum 18 years, maximum 71 years, median 30.0). Table 1 shows in which regions the women were born. The majority of women $(50.6 \%)$ were born in a country in Eastern Europe. Perpetrators born in the Netherlands constituted more than a quarter $(25.9 \%)$ of the research group.

\section{Prosecution characteristics of women convicted for human trafficking}

In this section, all cases $(N=138)$ will be discussed, as this section is based on the data from the judicial documentation. In $7.2 \%$ of cases $(N=10)$, no decision was known yet. In $11.5 \%$ of the cases $(N=16)$, there is a policy dismissal, for example because the suspect is untraceable, there is insufficient national interest, the suspect is accountable for a small part of the offense, or the defendant has already been affected by the facts and consequences. These policy dismissals count as a valid decision and can, therefore, be viewed as someone convicted of this offense [31]. In $81.2 \%$ of the cases $(N=112)$, the case resulted in a conviction.

Table 2 depicts how often specific sanctions have been imposed. If a sanction was imposed by the court, more than three quarters $(77.6 \%)$ of all women had a prison

\footnotetext{
${ }^{2}$ The data were supplied in Spring 2016, which explains the low number of suspects in that specific year.
} 


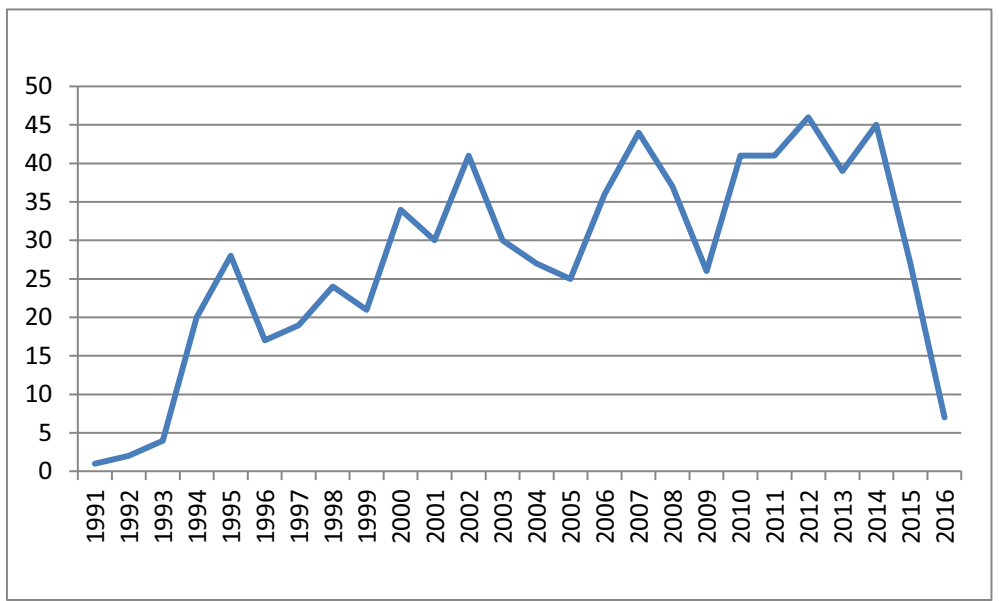

Fig. 1 Number of female suspects of human trafficking between 1991 and 2016

sentence with an unconditional part or a completely unconditional prison sentence. The average number of unconditional days the women had to spend in detention was 479 ( minimum $=2$, maximum $=1825, \mathrm{SD}=453$ ).

\section{Offender characteristics}

The results in the following sections are based on the 96 cases which were able to analyze through scoring the court files or having obtained information about the case through rechtspraak.nl.

From the legal article used in the past decades for the description of human trafficking (273f, 273a 250ter, 250a), specific forms of exploitation are not identified. However, this information could be retrieved from the court files. This information showed that the majority of women, $85(88.5 \%)$, were convicted for sexual exploitation and $11(11.5 \%)$ for labor exploitation. Trafficking in human beings with the aim of organ removal, forced marriage, forced adoption, and criminal exploitation were not present in the research group.

Of the women convicted of sexual exploitation (85), 50.8\% had worked as a prostitute, and $28.3 \%$ still worked as a prostitute at the time of the offense. It is striking

Table 1 Region of birth of women convicted for human trafficking

\begin{tabular}{ll}
\hline Region of birth & $\%$ (absolute numbers) \\
\hline Eastern-Europe & $50.4 \%(69)$ \\
Netherlands & $25.9 \%(36)$ \\
Asia & $9.4 \%(13)$ \\
South America & $6.5 \%(9)$ \\
Africa & $5.0 \%(7)$ \\
Western Europe & $2.2 \%(3)$ \\
Unknown & $0.7 \%(1)$ \\
Total & $100 \%(138)$ \\
\hline
\end{tabular}


Table 2 Imposed sanctions

\begin{tabular}{ll}
\hline Type of penalty & $\%(\mathrm{~N})$ \\
\hline Prison sentence, unconditional & $77.6 \%(87)$ \\
Community service order & $13.4 \%(15)$ \\
Prison sentence, conditional & $4.5 \%(5)$ \\
Unconditional fine & $2.7 \%(3)$ \\
Conditional fine & $0.9 \%(1)$ \\
Guilty but without a sanction & $0.9 \%(1)$ \\
Total & $100 \%(112)$ \\
\hline
\end{tabular}

that few characteristics about the perpetrator were present in the court files. Apart from the country of birth and place of birth, and whether the women were active in prostitution, little was mentioned about personal characteristics. For only 9 women, information was available from, for example, the probation service, and for 5 women (3.6\%) this report was also physically present in the criminal file.

Less than a third $(31.3 \%)$ of the women confessed (a part of) the offense. There was no difference in confessing between women involved in sexual exploitation or labor exploitation. As an explanation for committing the offense, the women indicated, among other things, that they were afraid of their male co-offender and, therefore, contributed to the exploitation, that they cooperated out of love for their male cooffender, that they had committed the offense because of the money ('illegal employees work harder than legal employees'), or that by having an extra income they could stop working as a prostitute themselves. Finally, some women mentioned that they wanted to help the victim(s) because they could earn more money working as a prostitute in the Netherlands than in their country of origin.

\section{Offense characteristics}

The majority (94.7\%) of women committed the offense together with others. On average, the partnerships consisted of 3.1 perpetrators (including the female perpetrator). The majority of the co-offenders were male $(75.3 \%)$, whereas a minority of the women had male and female co-offenders (13.8\%), or only female co-offenders $(1.4 \%)$. It is striking that for many women $(72.7 \%)$, their co-offender was also the man with whom they have or have had a romantic relationship. There was no significant difference for the women involved in sexual exploitation and those involved in labor exploitation. On average, 4 victims were involved in the offense. Except for one case (involving a transsexual victim), only female victims were involved in the cases of sexual exploitation. In the cases of labor exploitation, only male victims were mentioned 6 times, 3 times male and female victims, and 2 times only female victims.

\section{Behavioral acts committed by the women}

The behavioral acts for which the women were convicted diverged considerably. An overview of the behaviors as described in the files is presented in Table 3. The total 
Table 3 Behavioral acts as described in the files

\begin{tabular}{ll}
\hline Behavioral acts & Number of times \\
\hline Collecting money & 44 \\
Housing victims & 28 \\
Controlling during work & 25 \\
Exploiting victims & 24 \\
Taking away and keeping passports/travel documents & 21 \\
Recruiting outside the Netherlands & 19 \\
Connecting with potential customers & 17 \\
Pursuing minors to work in prostitution & 17 \\
Transporting to customers or workplace & 17 \\
Arranging forged travel documents, taking photos for travel documents, & 17 \\
$\quad$ arranging airline tickets & \\
Giving work instructions & 11 \\
Buying work related items for the victims & 8 \\
Renting windows & 7 \\
Administrating income & 7 \\
Enrolling to escort agency & 6 \\
Creating/ managing internet ads & 5 \\
Knowledge of exploitation & 5 \\
\end{tabular}

number of actions is more than 96, because women may have been convicted for performing several actions. Therefore, only absolute numbers and no percentages are mentioned in this table.

The five most common acts mentioned were collecting money (44), housing victims (28), controlling victims during their work (25), exploiting (24), and taking away and keeping passports or travel documents (21). It was difficult to derive the level of management from the files: women often denied a certain degree of management, probably as a criminal defense strategy. They turned in male perpetrators or victims provided contradictory statements about who had the day-to-day management in, for example, the sex club where they worked. Because of this contradiction and ambiguity, it was decided not to make any further statements about this aspect. Below, the roles and behaviors of the women are explained in more detail on the basis of a number of issues. Three cases of sexual exploitation and one case of labor exploitation are described, since this distribution reflects the prevalence in the data. For the cases of sexual exploitation one case with a solo offender was selected and two cases with cooffenders, since this is also representative of the data. Finally, to provide an adequate image of the data, a co-offender with an underaged victim and a cooffender with an adult victim were selected.

Brigitta was a 29-year-old Hungarian woman. She has been found guilty of trafficking 4 young Hungarian women, together with her Hungarian husband and a second Hungarian man, over a period of 4 years. The women were brought to the Netherlands under false pretenses (working as a dancer). Brigitta and her husband accommodated 
the women and they were not allowed to go outside independently or travel to their windows in the prostitution area. Everyday the women were told they had a large debt and had to recoup this. The debt was also increased through substantial fines, for example if a woman had spoken to a co-occupant or had smoked during working hours. The women were checked every day and, fearing they and their family were being affected, they did not dare to leave Brigitta and her co-offenders. To keep the victims 'under control', they were sometimes raped by the men. Brigitta claimed to the Court that she was under pressure of her husband. This was not deemed plausible because her husband spent a period abroad and was detained for a period of time. According to the court, Brigitta could have made other choices. The Court of Appeal imposed a prison sentence of 30 months, of which 16 months conditional.

Rose was a 35-year- old Dutch woman who was working as an escort-girl. She was looking for a girl with whom she could advertise for threesomes and, therefore, she asked the 17-year-old victim. Rose had met the victim previously at parties and she knew the victim was interested because she needed money. She knew the victim was underaged. Rose told the victim that her boyfriend had cheated on her and that there was no reason anymore for the victim to consider his feelings regarding working as an escort-girl. If the victim would not cooperate, she would get beaten up. The exploitation took place during a couple of weeks. In court, Rose told that she did not threaten the victim but that she was aware that she should not have asked the victim to join her because she was under 18 . Rose was convicted to a community service order of $100 \mathrm{~h}$.

Inge was a 22-year-old Dutch woman. For a period of a week, she and her boyfriend Jan encouraged a 16-year-old girl to work as a prostitute. Jan picked up the victim at a train station after she ran away from a youth institution. Inge placed advertisements on kinky.nl (a sex website), and made arrangements with customers for the victim. The victim was instructed to tell she was an adult. She was brought to customers and checked by Inge and Jan. She was instructed to have unprotected sex because this resulted in more money. The victim filed a report after a week. Inge said "If I had known it afterwards, I would never have done it. I never forced her, it was all voluntary. She wanted everything herself. I do not know how old she was. At one point she left and started working for someone else. Others have also stated that she had worked as a prostitute before. I think it is all very much exaggerated ". The court imposed a prison sentence of 6 months.

Yena was a 54-year-old Chinese woman. For a period of 4 months, she and her Chinese husband employed an illegal Chinese man in their restaurant. The man had to do preparatory work there, such as cutting meat and vegetables, and cleaning. He worked 6 to 7 days a week, $10 \mathrm{~h}$ a day. For these activities, he received $€ 800$ per month, including board, lodging, and holiday allowance. During audits by authorities, an alarm signal was used and the man had to hide in a secret hideout. The victim received too little salary, but he did not dare to say anything about it to the couple. He had a fake passport and no residence permit. He suspected that if he would mention anything about his salary, he would be sent away immediately. It was difficult for him to find a job in the hospitality industry, so he was happy with everything he could find. The man was discovered during a labor inspection operation. Yena indicated that she consciously employed illegal workers because they worked harder (as it is more difficult for them to find work). The Court of Appeal imposed a conditional fine of $€$ 10,000 on the woman. 


\section{Victim characteristics}

Regarding the age of the victim, $32.3 \%$ of the cases involved a minor victim (under 18 years of age).

There was no difference between the cases involving sexual exploitation and labor exploitation.

However, women who co-offended with a romantic partner had significantly less often an underage victim than women who co-offended with someone with whom they were not romantically involved ((Chi2 $(1)=4.992, p<.05)$. Furthermore, underage victims were more often found working in the escort sector or the unlicensed prostitution sector (e.g. massage parlors, private brothels in someone's home, or street prostitution) (Chi2 $(1)=13.682, p<.001)$. In Table 4 , the birth regions of the victims are compared with the birth regions of the perpetrators. This table shows that, in the majority of cases, perpetrators and victims originate from the same region. Therefore, it is rare for a victim to have a perpetrator who was not born in the same country as he or she was born. The most important exception to this relates to women who were born in the Netherlands: they more often have victims from Eastern Europe than from the Netherlands.

For offenders originating from Eastern Europe, the three most common countries of birth were Hungary (19 times), Romania (10 times), and Bulgaria (9 times). When for these three groups was examined from which countries their victims originate, it showed that Hungarian perpetrators had Hungarian victims, Romanian perpetrators had $90 \%$ Romanian victims and 10\% Hungarian victims, and that perpetrators from Bulgaria had victims from Bulgaria.

\section{Deception and economic vulnerability}

In a third $(33.8 \%)$ of the cases, the victim was deceived. Victims were told that they would work in the Netherlands as an au pair, companion for seniors, cleaning lady, or dancer. In the Netherlands, the women were employed as prostitutes very soon, often within a few days. This also means that, for a majority of the victims, there was no deception, at least not in the sense of promising a particular profession. Among the victims who knew in which sector (prostitution, vegetable cultivation) they would work, there was a different kind of deception at a later stage, namely that they received no, or too little, of their earnings.

Table 4 Birth regions victims compared with birth regions offenders

Birth region victims

\begin{tabular}{llllllll} 
& \multicolumn{2}{c}{ Nether-lands } & Eastern Europe & Asia & South America & Africa & Total \\
\hline \multirow{2}{*}{ Birth region offenders } & Nether-lands & 8 & 13 & 0 & 0 & 1 & 23 \\
& Eastern Europe & 0 & 31 & 0 & 0 & 0 & 31 \\
& Asia & 1 & 1 & 4 & 0 & 0 & 6 \\
South America & 3 & 0 & 1 & 1 & 0 & 5 \\
Africa & 0 & 0 & 0 & 0 & 3 & 3 \\
Total & 12 & 45 & 5 & 2 & 4 & 68
\end{tabular}


Without exception, all victims were 'chosen' because of their economic vulnerability. Perpetrators sometimes also indicated this during their police questioning. In the cases of sexual exploitation, female sex club owners were genuinely surprised at what rate foreign prostitutes wanted to do their work. According to them, a Dutch prostitute would never have done this. Female victims of sexual exploitation indicated that they were already working in prostitution in their country of origin and had come to the Netherlands to earn more money here. They found the higher earnings attractive. Finally, because prostitution in the Netherlands is legal, this resulted in a more peaceful life. They no longer had to circumvent the police. In the case of Yena, discussed above, the woman preferred to have illegal employees, because they always worked harder than legal employees because of fear to be reported to the police.

\section{Sexually exploited female perpetrators}

The analysis of the court files demonstrates that only $7.5 \%(N=7)$ of the women were victims of sexual exploitation before they became perpetrators. In 2 cases there was a policy dismissal and the other 5 women received an unconditional prison sentence (of which 3 with a conditional part). These groups are too small to perform statistical analyses. Therefore, it was decided to describe three cases involving a victim who herself has become a perpetrator.

Selina is a 25 -year-old woman who was born in Latvia. She was approached in a discotheque in her homeland by Max, also originating from Latvia. He asked her if she was interested in earning a lot of money as an escort in the Netherlands. The distribution was $50 \%$ for Max and $50 \%$ for Selina. She was interested and she accompanied him to the Netherlands. In the Netherlands, she had to hand over her passport to Max. He registered her at several escort agencies. Every day she gave over $90 \%$ of her earnings to Max. When she protested against this, he said her money was safer with him than in the house where she lived with the other prostitutes. He told her that she could keep more money, if she went back to Latvia to recruit women for him who could work in the escort service in the Netherlands. Back in Latvia, Selina noticed that several women she spoke to did not respond enthusiastically to working in prostitution. When she approached women later on, she told them she could arrange work as a cleaner. By doing this, she managed to recruit at least one victim. In the Netherlands, the women were registered at an escort agency and Selina transported the victims by car to the customers. One of the victims filed a report after having been assaulted by Max. The Public Prosecutor decided to conditionally close the case (under which condition was not clear from the file or the judicial documentation).

Ivonne is a Russian student who is in her early 20 s. She came into contact with Dragan through a website. He told her that he had fallen in love with her and sent her text messages several times an hour telling her how much he loved her. He paid an airline ticket for her, so she could visit him. For a few months, they had a relationship in which Dragan and Ivonne visited expensive restaurants. Dragan bought designer clothes for her and they went on holiday together. At one point in time, he suggested her to work as an escort, so they would have more money. She could earn $€ 20,000$ per month. Ivonne gave all earnings to him, because that would be safer. He also told her that with all that money they could later raise many children. At the same time, however, he also forced her to undergo an abortion when it turned out she was 
pregnant. When Ivonne indicated that she no longer wanted to work in prostitution, Dragan proposed that she should approach her friends in order to have them work in prostitution. She succeeded regarding one friend. The women were working in window prostitution and were taken to the office during a police check, where they filed a report. The Public Prosecutor decided to close the case, because Ivonne was already sufficiently affected by all the facts and the consequences.

Lydia is a Hungarian woman who is in her 30s. She came to the Netherlands with a forged passport to work in a sex club. She had to hand over a large proportion of her earnings to the owner of the club. After a while, she stopped working as a prostitute and she became manager of the same sex club. In the period she was a manager, several minors worked in the club. She kept the passports of all victims (at least 9 women). She insulted the women, if they did not work hard enough, and beat up the women. All women had to pay an average of 4000 euros in costs to the club's owner. Lydia says she beat the women because she was told to do so by the owner. If she would not have done this, she would have been beaten up herself. She denies that she was the manager of the club. The Court considered the fact that Lydia should still be regarded as a victim in the period in which she was employed as a chief, and sees this as a reason to considerably mitigate the sanction. The Court imposed 12 months imprisonment, of which 3 months conditional.

\section{Discussion}

This study examined the characteristics of women who were convicted for human trafficking. The majority of the women $(90 \%)$ was convicted for sexual exploitation, the other $10 \%$ for labor exploitation. Regarding the Netherlands, these figures cannot be compared with research on male perpetrators, because research on human trafficking often does not distinguish between the various existing forms of human trafficking. This 90:10 ratio, however, does not seem to be unreasonable, since it was also found in previous case-level research [14].

Regarding prosecution and sanctioning, $80 \%$ of the cases resulted in a conviction. This is comparable with the $73 \%$ reported by the Dutch National Rapporteur on Trafficking in Human Beings [15]. The average number of unconditional days the women had to spend in detention was 495 , which is more or less in line with the 558 days as reported by the NRM [14]. It should be noted, however, that the NRM figures cover the period 2011-2015, whereas the current study covers the period 1993-2016.

The average age of women at the time of the offense was 32 years; this indicates they do not appear to differ from the research group as studied by the NRM and which consists mainly of male suspects [15]. Half of the women were born in a country in Eastern Europe and Dutch offenders constituted more than a quarter of the research group. These figures appear to be the opposite of those of male suspects; in those cases, half of the suspects were born in the Netherlands and a quarter came from Eastern Europe [15].

Of the women who have been convicted for sexual exploitation, half has ever worked in prostitution, and more than a quarter worked in prostitution at the time of 
the offense. A minority of the women, 7.5\%, were victims of sexual exploitation themselves before they became perpetrators.

The majority of the women $(94.7 \%)$ had co-offenders, and the offending groups on average consisted of 3.1 perpetrators. It is difficult to compare these numbers with previous research, since there is not much to compare with in the area of human trafficking. When this $94.7 \%$ is compared to other research on co-offending, this number seems to be quite high. For example, about $60 \%$ of the female sexual offenders have co-offenders [34]. Van Mastrigt and Farrington [29], not differentiating for the combination of gender and crime-type, reported that, for all offense types, women were more likely than men to engage in co-offending: $24 \%$ of the women had a co-offender, compared with $21 \%$ of the men. These numbers are, however, considerably lower, compared to the numbers on sexual offending and human trafficking.

Three quarters of the co-offenders were male. Furthermore, it is striking that, for many women $(72.7 \%)$, their co-offender was also the man with whom they had or had had a romantic relationship. On average, four victims were involved in the offense. The five most common trafficking behaviors carried out by women were: collecting money, housing victims, monitoring victims during their work, exploiting, and taking away and keeping travel documents. It is remarkable that these behaviors are gender-neutral: it is not necessary that they have to be performed by a woman. For example, housing and monitoring victims are not acts that could only be executed by women. These acts can just as well be executed by men. Therefore, it could be stated that these female offenders are probably quite similar to their male counterparts. Previous research [27] suggested that women participated in the more low-ranking activities. Conversely, this current research showed that female offenders can have many important, highranking roles as well.

Finally, in the majority of cases, offenders and victims originate from the same region, which was also reported in the latest report on human trafficking by the United Nations [27]. The most important exception regards women who were born in the Netherlands: they are more often involved with victims from Eastern Europe than from the Netherlands.

\section{Theoretical and methodological reflections}

These research findings add to the theoretical and empirical understanding of the phenomenon of human trafficking for sexual exploitation. First, a part of the literature conceptualizes the role of women in the wrong way: women should not only be viewed as victims, but can also play roles of offenders. Second, these roles are not exceptional, as is clear from this research. Third, for a large part, these roles cannot be explained by specific experiences, such as a history of victimization of sexual exploitation before becoming a perpetrator. Fourth, the types of roles women fulfill as offenders are not only involve low-raking activities, but can be similar to those of men as offenders. Finally, the frequent presence of male co-offenders clealrly shows that offending is embedded in social relationships, including intimate (romantic) relationships (e.g. [30]), and calls for further research.

As mentioned previously, almost half of the cases were unavailable for analysis. Recent research of criminal cases shows that in more than $92 \%$ of all cases appeal 
requests are made by the suspect [5]. This means that a selective dropout might have occurred in the current study which may have influenced the results: recent cases in which the suspect disagreed with the sentence are, therefore, probably underrepresented. This could mean, among other things, that there could be an underrepresentation of cases in which technology plays a more prominent role, for example in the form of prostitution websites and websites where exploitation takes place through a webcam Future research may provide more insight into these more recent phenomena.

This study showed that only $7.5 \%$ of the women were victims of sexual exploitation before being convicted as perpetrators. However, since a relatively large number of files was unavailable for analysis, there is a chance of underreporting victimization. If a person is classified as a victim on the basis of international provisions or national law, the non-punishment principle can be invoked. Article 8 of the Warsaw Convention lays down a provision which - briefly - means that victims who have committed offenses in an exploitation situation must not be prosecuted or punished. Therefore, cases in which a female suspect was also a victim of sexual exploitation, could possibly not end up in court. These cases that entail the non-punishment principle are not studied, since only the cases in which someone has been convicted were analyzed.

This leads to four recommendations for follow-up research. First, when they become available, the files of the appeal cases should also be analyzed. In this way, more recent developments can also be considered.

The second recommendation concerns the fact that the cases in this study originate from four districts. This amounts to one third of all human trafficking cases where a female perpetrator has been convicted. Too little is known about the differences between these districts themselves, when it comes to trends in trafficking and sexual exploitation. That is why there is little to say about the effect of this geographical distribution. In order to get a better and more complete picture of female perpetrators of human trafficking, it is, therefore, advisable to also investigate cases in the other districts.

The third recommendation concerns the method of investigation. Less than a third of the women confessed involvement in (a part of) the offense. For even fewer women, it was possible to find out what their motives had been for committing the offense. It is possible that criminal records do not contain the appropriate material to be able to say something about these aspects: most suspects and perpetrators try to minimize or deny their part in the offense and, therefore, will not give much insight into their actions. In the context of the prevention of sexual exploitation, however, it is important that to gain more knowledge about the motives of perpetrators. That is why it would be a good idea to interview female perpetrators and detainees in order to get more insight into their motives.

Finally, based on this research, it is difficult to draw conclusions about the transition from victimization to perpetration and to what extent female perpetrators of sexual exploitation who have been victims of sexual exploitation differ from female perpetrators who have not been victims of sexual exploitation. It is also premature to draw any conclusion about the application of the non-punishment principle in the Dutch legal system or in foreign legal systems which would argue for a specific study into cases where there are grounds for dismissal that can be used in the case of victimization of human trafficking. 


\section{Appendix 1 Scoringsinstrument courtfiles}

\section{Idnumber}

Case number

Individual Characteristics

Country of birth Use of medication

Residency status

What kind of psychological reports included in courtfile

IQ score

IQ score measured with what instrument

Neuroticism

Impulsivity

Extraversion

Sensation seeking

Moral development

Selfesteem

Suggestibility

Aggression regulation problems in childhood

Problems with authority in childhood

Antisocial behavior

Ever been depressed

Learning problems

Previos psychological treatment

Clinical disorders (DSM 5- Axis 1)

Personality disorders (DSM 5 - Axis 2)

Paraphilic disorders

Selfmutilation

Suicide attempt(s)

Drugsabuse in daily life

Alcohol abuse in daily life

Gambling

Activities during the day

Financial debts

Family background

Siblings

Birth order

1-parent family

Enuresis/encopresis

Birth complications

Substance use of mother during pregnancy

Parenthood before 21

Alcohol abuse family
Marital status

Previous romantics relationships

Current romantic partner delinquent?

Previous romantic partner(s) delinquent?

Current romantic partner violent?

Has children

Contact with children

Prostitution

What type of prostitution

Starting age prostitution

Duration prostitution (in months)

Eating disorder

Sexual behavior prior to 18 years

Experiences with pregnancy prior to 18 years

Coping abilities

Traumatic experiences

Highest completed education

Being bullied at school

Being a bully

Contact with friends

Delinquent friends

Truancy

Disruptive behavior/fighting at school

School drop-out

School performance

Previous offenses $($ self $=$ report $)$

Maltreatment

Maltreatment by whom

Physical abuse

Physical abuse by whom

Witness of sexual abuse

Witness of physical abuse/domestic violence Abuse/maltreatment experienced by siblings Sexual abuse 
Idnumber

Case number

Drugs abuse family

Unemployment

Delinquent parents/siblings

Psychopathology parents

Psychopathology siblings

Multiple caregivers

Contact with child protection/youth care/etc.

Offense characteristics

Working in prostitution at the time of the offence

Substance use during the offence

Solo/co-offending

When co-offending: Gender, ethnic background and relationship with co-offenders

Residency status co-offenders

Was the co-offender already living in the

Netherlands prior to the offence?

Fixed or flexible network/group?

Use of weapon during the offence

Role offender during the offence

\# victims

Gender victim(s)

Age victim(s)

Country of birth victims

In what business sector were the victims working?

Use of deceptive techniques by offenders?

How was the case brought to the attention of the police
Starting age sexual abuse

Duration sexual abuse

What type of sexual abuse

\# offenders

Vague sexual borders in the family

Mother victim sexual abuse

Father victim sexual abuse

Use of physical violence

Use of physical violence to control the victim

Behavioral acts committed

Why this/these victim(s)

Relationship with victim(s)

Offence period

Physical injuries

Role of the woman, according to herself

Role of the woman, according to her co-offenders

Role of the woman, according to the victim

emotie bij aanhouding en/of verhoor

Display of emotion when arrested/interrogated?

Level of planning before the offence

Victim empathy

Exploited/recruited in which countries/cities

- If the woman was sexually exploited herself, describe the process of victim to offender:

- General impression of the case/remarkable things

- Details regarding co-offenders

Open Access This article is distributed under the terms of the Creative Commons Attribution 4.0 International License (http://creativecommons.org/licenses/by/4.0/), which permits unrestricted use, distribution, and reproduction in any medium, provided you give appropriate credit to the original author(s) and the source, provide a link to the Creative Commons license, and indicate if changes were made.

\section{References}

1. Arsovska, J., \& Allum, F. (2014). Introduction: Women and transnational organized crime. Trends in Organized Crime, 17(1-2), 1-15.

2. Barry, K. (1995). The prostitution of sexuality: NYU Press.

3. Beare, M. (2010). Women and organized crime. Public safety Canada, Report No. 013, Canada. 
4. Broad, R. (2015). 'A vile and violent thing': Female traffickers and the criminal justice response. British Journal of Criminology, 55(6), 1058-1075.

5. Croes, M. (2016). De staat van het hoger beroep in het strafrecht [The state of appeal in criminal law]. Den Haag: WODC.

6. Gozdziak, E. M., \& Bump, M. (2008). Data and research on human trafficking: Bibliography of research based literature. Washington, DC: U.S. Department of Justice.

7. Hoyle, C., Bosworth, M., \& Dempsey, M. (2011). Labelling the victims of sex trafficking: Exploring the borderland between rhetoric and reality. Social \& Legal Studies, 20(3), 313-329.

8. Huisman, W., \& Kleemans, E. R. (2014). The challenges of fighting sex trafficking in the legalized prostitution market of the Netherlands. Crime, Law and Social Change, 61(2), 215-228.

9. Jeffreys, S. (2008). The idea of prostitution. North Melbourne: Spinifex Press.

10. Kleemans, E. R., \& van de Bunt, H. G. (1999). The social embeddedness of organized crime. Transnational Organized Crime, 5(1), 19-36.

11. Kleemans, E. R., Kruisbergen, E. W., \& Kouwenberg, R. F. (2014). Women, brokerage and transnational organized crime. Empirical results from the Dutch organized crime monitor. Trends in Organized Crime, $17(1-2), 16-30$.

12. Lo Iacono, E. (2014). Victims, sex workers and perpetrators: Gray areas in the trafficking of Nigerian women. Trends in Organized Crime, 17(1-2), 110-128.

13. Nadon, S. M., Koverola, C., \& Schludermann, E. H. (1998). Antecedents to prostitution:Childhood victimization. Journal of Interpersonal Violence, 13(2), 206-221.

14. NRM (Nationaal rapporteur mensenhandel en seksueel geweld tegen kinderen) (2013). Mensenhandel. Negende rapportage van de Nationaal rapporteur [ Human trafficking. Ninth report of the National Rapporteur]. Den Haag.

15. NRM (Nationaal Rapporteur Mensenhandel en Seksueel Geweld tegen Kinderen) (2016). Cijfers vervolging en berechting 2011-2015 [figures on prosecution and punishment]. Den Haag: BNRM.

16. Outshoorn, J. (2018). Policy reforms on prostitution: The quest for control. In S. Shaver (Ed.), Handbook on gender and social policy (pp. 90-109). Cheltanham: Elgar.

17. Raymond, J. G. (1998). Prostitution as violence against women: Ngo stonewalling in Beijing and elsewhere. Women's Studies International Forum, 21(1), 1-9.

18. Raymond, J. (2004). Prostitution on demand: Legalizing the buyers as sexual consumers. Violence Against Women, 10, 1156-1186.

19. Schwartz, J., \& Steffensmeier, D. (2015). Can the gender gap in offending be explained? In F. T. Cullen, P. Wilcox, J. L. Lux, \& C. L. Jonson (Eds.), Sisters in crime revisited. New York: Oxford University Press.

20. Siegel, D., \& de Blank, S. (2008). Vrouwen die in vrouwen handelen [Women who are trafficking women]. Tijdschrift voor Criminologie, 51(1), 3.

21. Silbert, M., \& Pines, A. (1982). Victimization of street prostitutes. Victimology, 7, 122-133.

22. Staring, R. (2007). Handelaars in vrouwen [Traffickers of women]. Justitiële Verkenningen, 33(7), 50-64.

23. Turner, J., \& Kelly, L. (2009). Trade secrets intersections between diasporas and crime groups in the constitution of the human trafficking chain. British Journal of Criminology, 49(2), 184-201.

24. UNODC. (2010). The Globalization of Crime: A Transnational Organized Crime Threat Assessment. United Nations Office on drugs and crime.

25. UNODC. (2012). Global report on trafficking in persons 2012. Vienna: UNODC.

26. UNODC. (2014). Global report on trafficking in persons 2014. Vienna: UNODC.

27. UNODC. (2016). Global report on trafficking in persons 2016. Vienna: UNODC.

28. Van Dijk, E., Bijkerk, R. P. F., \& van Soest, S. (2002). Mensenhandel in Nederland: 1997-2000 [human trafficking in the Netherlands: 1997-2000]. Apeldoorn: Korps Landelijke Politiediensten.

29. Van Mastrigt, S. B., \& Farrington, D. P. (2009). Co-offending, age, gender and crime type: Implications for criminal justice policy. British Journal of Criminology, 49(4), 552-573.

30. Verhoeven, M., van Gestel, B., de Jong, D., \& Kleemans, E. (2015). Relationships between suspects and victims of sex trafficking. Exploitation of prostitutes and domestic violence parallels in Dutch trafficking cases. European Journal on Criminal Policy and Research, 21(1), 49-64.

31. Wartna, B. S. J., Blom, M., \& Tollenaar, N. (2008). De WODC-Recidivemonitor [the WODC recidivismmonitor]. Den Haag: WODC.

32. Weitzer, R. (2005). Flawed theory and method in studies of prostitution. Violence Against Women, 11(7), 934-949.

33. Weitzer, R. (2015). Human Trafficking and Contemporary Slavery. Annual Review of Sociology, 41(1), $223-242$. 
34. Wijkman, M. D. S. (2014). Female sexual offending. Offenders, criminal careers and co-offending. (Ph.D.), Vrije Universiteit Amsterdam.

35. Wijkman, M., Bijleveld, C., \& Hendriks, J. (2010). Women Don't do such things! Characteristics of female sex offenders and offender types. Sexual Abuse: A Journal of Research and Treatment, 22(2), $135-156$.

36. Zhang, S. X. (2009). Beyond the 'Natasha' story-a review and critique of current research on sex trafficking. Global crime, 10(3), 178-195.

37. Zhang, S. X., Chin, K. L., \& Miller, J. (2007). Women's participation in Chinese transnational human smuggling: A gendered market perspective. Criminology, 45(3), 699-733.

Publisher's note Springer Nature remains neutral with regard to jurisdictional claims in published maps and institutional affiliations. 